ISSN 2338-5324 (print)

ISSN 2442-7276 (online)

Online di http://jkp.fkep.unpad.ac.id

DOI : $10.24198 / \mathrm{jkp}$

\title{
The Factors that are Related to Self-Care Agency in Patients with Hypertension
}

\author{
Dendy Kharisna ${ }^{1}$, Helwiyah Ropi ${ }^{2}$, Urip Rahayu ${ }^{2}$ \\ ${ }^{1}$ Institute of Health Science Payung Negeri Pekanbaru, ${ }^{2}$ Faculty of Nursing, Universitas Padjadjaran \\ Email:dendykharisna@gmail.com
}

Submitted: 24-4-2017 Accepted: 27-4-2018 Published: 30-4-2018

\begin{abstract}
Uncontrolled hypertension leads to complex problems experienced by patient as the complication of the hypertension. The patient's ability to do self-care (self-care agency) is essential and recommended to control hypertension. Age, sex, education, occupation, marital status, decision making, duration of hypertension, lifestyle, and insurance availability are contributed to the self-care agency. Nurses and patients should be able to know and understand these self-care agency related factors. The aim of this study was to identify self-care agency relating factors of hypertension patients in Pekanbaru. This study conducted using a quantitative approach with cross sectional design and involving 100 hypertension patients who recruited using purposive sampling techniques. Self-care agency was measure using exercise of self-care agency (ESCA) questionnare. Data were analyzed using Spearman test and Chi Square test to determine the relation of each factors on self-care agency and multivariate logistic regression test to determine the most related factors on self-care agency. The result showed that there were a significant different of age $(p=0.048)$, education $(p=0.002)$, gender $(p=0.025)$, health insurance $(p=0.027)$, and life style $(p=0.003)$ with self-care agency. Meanwhile, there were no signifcant different of occupation ( $\mathrm{p}=1.000)$, decision making $(\mathrm{p}=0.800)$, marital status $(\mathrm{p}=1.000)$, and duration of hypertension $(\mathrm{p}=0.567)$ with self-care agency. Multivariate analysis revealed that the most influence factor for self-care agency is life style. This study suggest the nurses in improving self-care agency of hypertension patients must concern about patient lifestyle and help patient to modify their lifestyle.
\end{abstract}

Keywords: Hypertension, patients, self-care agency. 
Dendi Kharisna : The Factors that are Related to Self-Care Agency in Patients with Hypertension

\section{Introduction}

Hypertension is one of the most deadly chronic diseases in the world by contributing 9.4 million mortality every year (WHO, 2013). WHO data states that some of the developing countries $(40 \%)$ have hypertensive patients. In Southeast Asia, 36\% of adults suffer from hypertension and 1.5 million die each year. The number of people with hypertension is predicted to increase sharply in 2025 where about 29\% (1.6 billion adults) worldwide will suffer from hypertension (Kementerian Kesehatan RI, 2013).

Prevalence of hypertension in Indonesia inclined increase every year. According to the data of Riset Kesehatan Dasar (Riskesdas) in 2013 the prevalence of hypertension in Indonesia reaches $25.8 \%$ in the age range above 18 years and ranks 6th of 10 noncommunicable diseases in Indonesia. The highest incidence was found in Bangka Belitung at $30.9 \%$, South Kalimantan with $30.8 \%$, East Kalimantan with $29.6 \%$ and West Java with $29.4 \%$. While in Riau Province as much as $20.9 \%$ (Kementerian Kesehatan RI, 2013).

Based on data from Dinas Kesehatan Propinsi Riau tahun 2012 showed that the incidence of essential (primary) hypertension was ranked third for outpatient noncommunicable visits with 742 cases. As for hospitalization, essential hypertension ranks second with 343 cases (Dinas Kesehatan Propinsi Riau, 2012). This figure increases in the year 2013 from the results of integrated surveillance of disease (STP) district/city health centers, hypertension ranks third of the 10 highest disease in Riau as much as 4182 cases (Dinas Kesehatan Propinsi Riau, 2013). Data from Dinas Kesehatan Kota Pekanbaru (2015) showed hypertension ranks first in the top ten cases of non-communicable diseases in health centers in Pekanbaru as many as 36,476 visits. The profile data also shows that hypertension is second in the top ten disease types in public healt centre by 2015 with an incidence rate of 31,437 .

Hypertension is a disease that occurs caused by high systolic and diastolic blood pressure. Many factors that can cause the occurrence of hypertension, one of them is unhealthy lifestyle. This is evidenced by the high incidence of hypertension in people who have smoking habits, lack of activity, do not consume healthy food, have a weight above normal (obesity), and high stress levels (Riskesdas, 2007).

Hypertension can lead to the emergence of several complications such as damage to the heart, brain, kidneys, and eyes (Allen, 2011). Uncontrolled hypertension can lead to kidney failure caused by elevated levels of angiostin so that the kidneys are damaged. In addition, hypertension also affects the decline in body function, increased risk of memory loss (dementia), and ability to take care of themselves (American Heart Association [AHA], 2007). Uncontrolled hypertension also causes microalbuminemia, stroke and heart attack (Messerli, William, \& Ritz, 2007).

Onwuchekwa, Asekomeh, Iyagba, and Onung (2010) conducted a review of mortality rates against 424 hypertensive patients in Nigeria. $39.9 \%$ of patients had a stroke as a result of complications of hypertension, heart failure $(22 \%)$, kidney failure $(9.4 \%)$, and encephalopathy $(1.7 \%)$. Death rates due to complications of hypertension caused by stroke $(51.5 \%)$, heart failure $(14.12 \%)$, and kidney failure $(12.1 \%)$. In the same period Onwuchekwa also found out of 191 cases of death in cases of hypertension, $85 \%$ of deaths occurred during acute hypertensive crisis that included stroke, encepalopathic hypertension, and acute renal failure. Other complications that lead to death are caused by heart failure $(17.3 \%)$ and renal failure (16.8\%). The high rate of morbidity and mortality caused by complications of hypertension is not apart from uncontrolled hypertension.

Based on data from the statistics of heart disease and stroke in 2012, during the years 2005-2008 found the incidence of hypertension occurs at the age of 20 years and the elderly. A total of $79.6 \%$ of patients are aware of hypertension and $70.9 \%$ of them undergoing treatment. However, only 48\% of patients were able to control their blood pressure below 140/90 $\mathrm{mmHg}$, while 52\% were unable to control their blood pressure (Roger et al., 2012). The low control of hypertension was also obtained by Hajjar and 
Dendi Kharisna : The Factors that are Related to Self-Care Agency in Patients with Hypertension

Kocthen (2003) in his study by looking at trends in the prevalence, awareness, treatment and control of hypertension in 1988-2000 in the United States. The results showed that during the year the treatment and control of hypertension was only $31.0 \%$.

Blood pressure control is important for patients with hypertension. The study results showed a decrease in blood pressure will reduce the risk of cardiovascular disease and other vascular complications. A decrease in blood pressure can reduce the risk of stroke by $20-25 \%$ and the risk of heart failure by $50 \%$ (Burrows \& Muller, 2007). Therefore, uncontrolled hypertension will increase the complications and mortality rates of hypertensive patients. Poor behaviors control of hypertension indicate poor management of hypertensive patients who are the leading cause of death in public health services in China (Hu, Li, \& Arao, 2013).

In Indonesia, the level of awareness, treatment, and control of hypertension is very low. Krishnan, Garg, and Kahandaliyanage (2013) conducted a study of the incidence of hypertension in Southeast Asia. The study shows that the level of awareness of hypertensive patients in Indonesia related to hypertension status is the lowest among other ASEAN countries, only $24.0 \%$. Meanwhile for the number of handling and control is not reported at all. This indicates that the proportion of hypertensive patients whose blood pressure is controlled is very small. The low level of awareness, handling, and controlling blood pressure performed by the patient results in high problems due to complications of hypertension (Ogah et al., 2012). Therefore, it is necessary to make the right effort for patient to improve their control behavior and reduce the number of complications.

One approach that can improve patient's blood pressure control is the involvement of the patient itself in self-care. Sadeghi, Shiri, Roohafza, Rakhshani, Sepanlou, and Sarrafzadegan (2013) recommend a selfcare model to be implemented and used in the care of patients and families with hypertension. Sadeghi et al. says that selfcare is an effective and successful method of controlling hypertension. By applying self-care the patient will be able to improve his lifestyle to control the disease by using existing resources.

The ability of self-care is important for patient with hypertension. This is due to success of hypertension treatment depends on the patient's ability to control various risk factors for high blood pressure. Self-care focuses on the value and aspect of active empowerment and engagement of the patient in achieving the goal of care and maintaining their health condition. Self-care aims to allow patients to care for and meet their own needs ranging from biological, psychological, developmental, and social needs in managing health and well-being. When patients are unable to meet their needs, self-care will not be effective. This condition certainly affects the quality of life and the patient's family. Therefore, it is important for the nurse to look for what is needed by the patient, why the patient is not able to do self-care well, what affects the patient's ability to care for themself and what to do to meet the patient's care needs (Potter \& Perry, 2009).

Orem says self-care is a "human regulatory function" which means that every act of care is based on individual abilities. Any activity that an individual undertakes in improving, maintaining, or restoring their health status is called self-care. Nurses play a role in helping patients achieve optimal health by providing care or health education aimed at establishing patients so that patients are able to adapt to the illness condition. This is in line with hypertension patient's goal of controlling blood pressure and minimizing the incidence of complications with lifestyle modification (Smeltzer, Bare, Hinkle, \& Cheever, 2010).

Individual self-care behavior is seen by assessing the ability of self-care patients known as self-care agencies (SCAs). There are 3 components that are included in the ability of self-care, the knowledge, the need in making decisions to behave, and resources both physical, psychological, emotional, and material. These three components of the self-care agency will be used to predict the behavior of self-care of a person or patient (Meleis, 2012). Self-care is influenced by internal and external factors (Srikan, 2012). Factors affecting self-care are known as basic 
Dendi Kharisna : The Factors that are Related to Self-Care Agency in Patients with Hypertension

conditioning factors that include age, gender, education, health status, developmental stage, socio-culture, health care system, environment, family support, lifestyle, and resource availability (Callaghan, 2005; Orem, 2001).

Orem (2001) says that patients should be able to develop knowledge and understanding of the factors that affect self-care needs and the ability of self-care. Likewise with nurses, it is necessary to understand the characteristics of the patient so that it can be better in providing assistance and collaborating. Knowledge of basic conditioning factors affecting the patient's self-care agency can assist nurses in predicting the type and amount of assistance received by the patient. Nurses should also have an insight against their own basic conditioning factors as they will affect the nursing agency and nursing care provided to the patient.

Some studies show and explain relationship between age (Ranpenning \& Taylor, 2003; Kamrani et al., 2014; Daryasari, Karkezloo, Mohammadnejad, Vosooghi, \& Kagi, 2012; Khresheh \& Mohammed, 2016; Sousa, Zauszniewski, Musil, Lea, \& (Coyle, 2000; Sousa, Zauszniewski, Musil, Lea, \& Davis, 2005), education, occupation (Akyol, Cetinkaya, Bakan, Yarali, \& Akkus, 2007; Hu, Li, \& Arao, 2013; Oksel, Akbiyk, \& Koca, 2009), and marital status (Istek \& Karakurt, 2016; Alizadeh, Ashktorab, Nikravan, Mofrad, \& Zayeri, 2014; Dunbar, Clark, Quinn, Gary, \& Kaslow, 2008) with self-care agency.

Several previous studies have mentioned that in addition to age, sex, education, employment and marital status, there are other factors that related to self-care agency of hypertensive patients, namely decision making (Dunbar, Clark, Quinn, Gary, \& Kaslow, 2008), health insurance (Akyol, Cetinkaya, Bakan, Yarali, \& Akkus, 2007; Callaghan, 2005), lifestyle (Sadeghi et al, 2013; Mersal \& Mersal, 2015), and duration of hypertension (Hu, Li, \& Arao, 2013). Based on the results of these studies there is no research about the most dominant factors that related to self-care agency in patient with hypertension. More over in Indonesia, research about factors that related to selfcare agency in patient with hypertension is rarely done. Therefore it is important to find out the factors that are related to the self-care agency, especially to find the most dominant factor in relation to the self-care agency of patients with hypertension.

Based on this condition, it is necessary to find the most related factors to self-care agency in patients with hypertension to help and facilitate nurse when determining the priority scale in the provision of nursing orders. On the other hand, it also potential to assist patients in improving self-care agency that is useful in controlling hypertension. This is the main reason and interesting for researcher in doing research on "The Factors that are Related to Self-Care Agency in Patients With Hypertension in Pekanbaru".

\section{Method}

This research uses a quantitative approach with cross-sectional design which is a research design with observation or measurement at the same time (once) on the cause or risk variables and the consequences or cases that occur (Burn \& Grove, 2005). Population in this research is all patient of primary hypertension that exist in work area of Harapan Raya Public Health Centre in Pekanbaru. The sampling technique used in this research is purposive sampling. The samples were chosen by considering the inclusion and exclusion criteria set by the researcher. Dahlan (2010) and Sastroasmoro (2011) said that to determine the number of samples in a multivariate study, both the linear regression and logistic regression were performed using the rule of thumb with the benchmark of the independent variables studied. The recommended calculation is 10 times the number of independent variables studied plus the anticipated drop-out by $10 \%$. Thus the large sample in this study amounted to 100 patients with hypertension in the city of Pekanbaru in the work area of Harapan Raya Public Health Center in Pekanbaru. Data were analyzed by using chi square and multivariate logistic regression test. 
Dendi Kharisna : The Factors that are Related to Self-Care Agency in Patients with Hypertension

\section{Result}

Table 1 Distribution of Respondents by Age, Sex, Education, Occupation, Marital Status, Decision Maker, Duration of Hypertension, Health Insurance, and Lifestyle $(n=100)$

\begin{tabular}{|c|c|c|}
\hline Variable & Frequency & Percentage (\%) \\
\hline \multicolumn{3}{|l|}{ Age } \\
\hline Early Adult (18-40) & 15 & 15 \\
\hline Mid Adult (41-60) & 63 & 63 \\
\hline Late Adult $(>60)$ & 22 & 22 \\
\hline \multicolumn{3}{|l|}{ Gender } \\
\hline Woman & 69 & 69 \\
\hline Man & 31 & 31 \\
\hline \multicolumn{3}{|l|}{ Education } \\
\hline SD & 39 & 39 \\
\hline SMP & 10 & 10 \\
\hline SMA & 30 & 30 \\
\hline PT & 21 & 21 \\
\hline \multicolumn{3}{|l|}{ Occupation } \\
\hline Work & 45 & 45 \\
\hline Does Not Work & 55 & 55 \\
\hline \multicolumn{3}{|l|}{ Marital Status } \\
\hline Married & 98 & 98 \\
\hline Not Married & 2 & 2 \\
\hline \multicolumn{3}{|l|}{ Decision-Making } \\
\hline Respondents & 16 & 16 \\
\hline Discussion/Family/Others & 84 & 84 \\
\hline \multicolumn{3}{|l|}{ Duration of Hypertension } \\
\hline 0,5 years -1 year & 29 & 29 \\
\hline$>1$ year -3 years & 41 & 41 \\
\hline$>3$ years & 30 & 30 \\
\hline \multicolumn{3}{|l|}{ Health Insurance } \\
\hline Do Not Have Health Insurance & 43 & 43 \\
\hline Have Health Insurance & 57 & 57 \\
\hline \multicolumn{3}{|l|}{ Life Style } \\
\hline Good & 48 & 48 \\
\hline Not Good & 52 & 52 \\
\hline
\end{tabular}

Table 2 The Frequency Distribution of Respondents by Self-Care Agency $(\mathrm{n}=\mathbf{1 0 0})$

\begin{tabular}{lcc}
\hline \multicolumn{1}{c}{ Variable } & Frequency & Percentage (\%) \\
\hline SelfCare Agency & & \\
Good & 44 & 44 \\
Not Good & 56 & 56 \\
\hline
\end{tabular}


Dendi Kharisna : The Factors that are Related to Self-Care Agency in Patients with Hypertension

Table 3 Relationship Age, Education, Long Suffering Hypertension with Self-Care Agency

\begin{tabular}{lcc}
\multicolumn{1}{c}{$(\mathbf{n}=\mathbf{1 0 0})$} & $\mathbf{r}$ & $\mathbf{p}$ \\
\hline \multicolumn{1}{c}{ Variable } & -0.198 & 0.048 \\
Age & 0.310 & 0.002 \\
Education & 0.058 & 0.567 \\
Duration of Hypertension &
\end{tabular}

Tabel 4 Relationship of Sex, Occupation, Marital Status, Decision-Making, Lifestyle, and Ownership of Health Insurance with Self-Care Agency $(n=100)$

\begin{tabular}{|c|c|c|c|c|c|}
\hline \multirow[b]{2}{*}{ Variable } & \multicolumn{2}{|c|}{ Self-care Agency } & \multirow[b]{2}{*}{ n $(\%)$} & \multirow[b]{2}{*}{ OR $(95 \%$ CI $)$} & \multirow[b]{2}{*}{$\mathbf{p}$} \\
\hline & $\begin{array}{l}\text { Good } \\
\text { n (\%) }\end{array}$ & $\begin{array}{c}\text { Not Good } \\
\text { n }(\%)\end{array}$ & & & \\
\hline \multicolumn{6}{|l|}{ Gender } \\
\hline Woman & $8(25.8)$ & $23(74.2)$ & $31(100)$ & 0.319 & 0.025 \\
\hline Man & $36(52.2)$ & $33(47.8)$ & $69(100)$ & $(0.125-0.810)$ & \\
\hline \multicolumn{6}{|l|}{ Occupation } \\
\hline Work & $20(44.4)$ & $25(55.6)$ & $45(100)$ & 1.033 & 1.000 \\
\hline Does Not Work & $24(43.6)$ & $31(56.4)$ & $55(100)$ & $(0.467-2.285)$ & \\
\hline \multicolumn{6}{|l|}{ Marital Status } \\
\hline Married & 43 (43.9) & $55(56.1)$ & $98(100)$ & 0.782 & 1.000 \\
\hline Not Married & $1(50)$ & $1(50)$ & $2(100)$ & $(0.048-12.862)$ & \\
\hline \multicolumn{6}{|l|}{$\begin{array}{l}\text { Decision- } \\
\text { making }\end{array}$} \\
\hline Respondents & $8(50)$ & $8(50)$ & $16(100)$ & 0.750 & 0.800 \\
\hline $\begin{array}{l}\text { Discussion/ } \\
\text { Family }\end{array}$ & $36(42.9)$ & $48(57.1)$ & $84(100)$ & $(0.257-2.189)$ & \\
\hline \multicolumn{6}{|l|}{ Life Style } \\
\hline Good & $29(60.4)$ & $19(35.6)$ & $48(100)$ & 3.765 & 0.003 \\
\hline Not Good & $15(28.8)$ & $37(71.2)$ & $52(100)$ & $(1.636-8.664)$ & \\
\hline \multicolumn{6}{|l|}{$\begin{array}{l}\text { Health } \\
\text { Insurance }\end{array}$} \\
\hline $\begin{array}{l}\text { Do not have } \\
\text { health insurance }\end{array}$ & $31(54.4)$ & $26(45.6)$ & $57(100)$ & 2.751 & 0.027 \\
\hline $\begin{array}{l}\text { Have health } \\
\text { insurance }\end{array}$ & $13(30.2)$ & $30(69.8)$ & $43(100)$ & $(1.195-6.334)$ & \\
\hline
\end{tabular}

Table 5 Results of Bivariate Selection Factors Associated with Self-care Agency in Patients with Hypertension

\begin{tabular}{lc}
\hline \multicolumn{1}{c}{ Variable } & P Value \\
\hline Age & 0.004 \\
Gender & 0.016 \\
Education & 0.000 \\
Occupation & 0.935 \\
Marital Status & 0.836 \\
Decision-Making & 0.599 \\
Duration of Hypertension & 0.038 \\
\hline
\end{tabular}


Dendi Kharisna : The Factors that are Related to Self-Care Agency in Patients with Hypertension

\begin{tabular}{ll}
\hline Health Insurance & 0.017 \\
Life Style & 0.000 \\
\hline
\end{tabular}

Table 6 Final Model of Multivariate Analysis of Logistic Regression $(n=100)$

\begin{tabular}{cccccc}
\hline \multirow{2}{*}{ Variable } & \multirow{2}{*}{$\mathrm{B}$} & \multirow{2}{*}{$\mathrm{P}$} & $\mathrm{OR}$ & \multicolumn{2}{c}{ CI 95\% } \\
\cline { 5 - 6 } & & & & Min & Max \\
\hline Age & -0.058 & 0.018 & 0.943 & 0.899 & 0.990 \\
Life Style & 0.058 & 0.000 & 1.059 & 1.029 & 1.090 \\
\hline
\end{tabular}

Based on Table 1 it is found that most respondents have primary education level (39 people or $39 \%$ ) and duration of hypertension for> 1 year -3 years (41 people or $41 \%$ ). Most respondents aged 41-60 years (63 people or $63 \%$ ), women (69 people or $69 \%$ ), not working ( 55 people or $55 \%)$, have health insurance $(57 \%)$, and have a not good lifestyle (52 people or $52 \%$ ). The majority of respondents were married (98 people or $98 \%$ ) and took decisions through discussion (84 people or $84 \%$ ).

Based on table 2 it is known that most respondents have a poor self-care agency as many as 56 people $(56 \%)$.

Based on table 3 it is known that the variables of age and education have a significant relationship to the self-care agency in patients with hypertension. Age is negatively related, while education is positively related to self-care agency patients with hypertension.

Based on table 4 it is known that the $\mathrm{p}$ value on the gender variables (0.014), lifestyle (0.003), and health insurance ownership (0.027) is smaller than the alpha value $(0.05)$ which means there is a significant relationship between gender, lifestyle, and health insurance with self-care agency in patients with hypertension. The result of the analysis shows that female respondents have a good self-care agency as much as $52.2 \%$ compared to male respondents who only $25.8 \%$ with the value of OR 0.319 which means female respondents tend to have a good self-care agency 0.319 times compared to male respondents.

The analysis results on lifestyle variables found that respondents with a good lifestyle have a good self-care agency (26 people or $60.4 \%$ ). The OR value of lifestyle was 3.765 , meaning that respondents with a good lifestyle had a tendency to have a good selfcare agency as much as 3,765 times compared to respondents whose lifestyle is not good. The result of analysis on the variable of health insurance shows that the patient who has health insurance has a good self-care agency as many as 31 people $(54.4 \%)$. The value of $O R$ in the health insurance variable is 2.751, which means there is a tendency of respondents who have health insurance to have a good self-care agency of 2.751 times compared to respondents who do not have health insurance.

Based on table 5 it is known that the $\mathrm{p}$ values for the age variables (0.004), gender (0.016), education (0.000), long suffering from hypertension (0.038), health insurance holdings (0.017), and lifestyle (0.000) from 0.25 which means all these variables go into the multivariate modeling stage. Meanwhile for job variables (0.935), marital status (0.863), and decision making (0.598) do not meet the requirements for inclusion in multivariate modeling.

Based on the final analysis results of multivariate modeling found that variables related to self-care agency in patients with hypertension were age and lifestyle. Judging from the analysis results obtained the largest Odds Ratio (OR) values exist in lifestyle variables. This suggests that lifestyle is the most dominant factor that related with selfcare agency in patients with hypertension after controlled with age variable.

The equation derived from the multivariate modeling using the formula, $y=$ constant + $\mathrm{a} 1 \mathrm{x} 1+\mathrm{a} 2 \mathrm{x} 2+\ldots \ldots+\mathrm{ax} \mathrm{xx}$ where $\mathrm{a}$ is the coefficient value of each variable and $\mathrm{x}$ is the 
Dendi Kharisna : The Factors that are Related to Self-Care Agency in Patients with Hypertension

value of the independent variable then the equation is obtained as follows:

$\mathrm{y}=0.698+-0.058$ (age) +0.058 (lifestyle)

Based on the equation, it can be seen that respondents with a good lifestyle have a tendency to have a good self-care agency 0.058 times after controlled with age variables. This is significant in improving self-care agency of respondent nurses should pay attention to respondent's lifestyle and able to direct respondent to modify lifestyle according to recommendation in patients with hypertension.

\section{Discussion}

Discussion of univariate, bivariate, and multivariate analysis includes age, gender, education, occupation, marital status, decision making, duration of hypertension, lifestyle, and health insurance. The result of bivariate analysis shows that there is a correlation between the variables of age, gender, education, lifestyle, and health insurance against self-care agency, while occupation variables, marital status, decision making, and duration of hypertension are not related to self-care agency.

The results of this study indicate that the age variable associated with self-care agency with $p$ value $0.048(<0.05)$. There is a negative relationship between the age variable and the self-care agency of respondents. This is in accordance with Orem (1995, in Ranpenning and Taylor, 2003) who say that self-care agency increases during childhood until adulthood, but will decrease in elderly. The same study was obtained by Akhter (2010) on self-management in hypertensive patients in Bangladesh. The study showed that self-management in the middle and young adult respondents better than the final adult respondents.

Sundsli, Soderhamn, Espnes, and Soderhamn (2012) in their study also found a negative association between age and selfcare agency $(r=-0.126, p<0.001)$. The study shows that increasing age will increase risk factors for decreased self-care ability. The study found that when entering old age, the respondents at risk of changes in nutritional status, respondents are at risk of nutritional deficiencies and also become lack of physically. Nutrition is an important thing in self-care where older respondents tend not to meet certain nutritional needs appropriately. Similar studies were also obtained by Soderhamn and Bachrach-Lindstrom (2008) in which $69 \%$ of respondents reported being at risk of nutritional distress at high risk of adverse health outcomes and decreased of self-care ability.

Weinger, Beverly, and Smaldone (2014) explained that when a person getting older, he will experience changes in health status, physical and mental abilities, and also the fulfillment of nutritional needs that will interfere with his self-care behavior. Other studies also showed a negative association between age and self-care behavior in hypertensive patients (Yang, Jeong, Kim, \& Lee, 2013). Therefore, patients or elderly persons should be given support in order to maintain their ability and self-care behavior and health status.

The next variable is gender. The results of this study indicate that there is a significant relationship between gender and self-care agency with $\mathrm{p}$ value $0.014(<0.05)$. Female respondents $(52.2 \%)$ had a better self-care agency than male respondents $(25.8 \%)$. These results are similar to $\mathrm{Hu}, \mathrm{Li}$, and Arao (2013) who also found that female respondents had better self-care than male respondents. Coyle (2000) says that gender is one of the basic factors that can affect the ability and needs of self-care as well as relating to dependent care and the need for dependent care. The tendency of female respondents to have better behavior and ability in performing selfcare than male respondents are influenced by social and cultural factors. This indirectly prevents women from unhealthy behaviors and habits commonly done by men, such as smoking and consuming alcohol (Yang et al., 2008).

Respondents in this research are very demanding women in order to maintain and care for their families well. A woman especially who has married is expected to meet the needs of family members. Women act as financial managers and usually also take control of decisions made by the family, including in terms of managing family health. In addition, the majority of female 
Dendi Kharisna : The Factors that are Related to Self-Care Agency in Patients with Hypertension

respondents have sufficient time to self-care and tend to be more active and concerned about their health than male respondents.

Other studies that support is Sousa, Zauszniewski, Musil, Lea, and Davis (2005) who found gender have a meaningful contribution to self-care behavior in diabetic patients. The study showed that female respondents had better self-care behavior than male respondents. The findings of this research also explains that women have a more caring attitude and pay more attention to the health status and disease suffered so as to try to do self-care optimally.

Educational variables also showed significant relationship with self-care agency of respondents with $p$ value $0.002(<0.05)$. The results of this study are similar to Coyle (2000) who said that the strength and ability of self-care is a behavior that is learned from childhood to adulthood and formal education role as a factor that affects the level of selfcare person. The results of this study are in line with the research of Akyol, Cetinkaya, Bakan, Yarali, and Akkus, (2007) on self-care agency and the factors that influence it on 120 hypertensive patients. The study shows that education is related to the patient's self-care agency. The leading cause is high education correlates with better work and income and affects one's self-care ability. Other studies have also shown a correlation between educational level and self-care ability, if the level of education is increase so the ability to self-care will also increase (Baghaiy, 2005).

Education is very influential on how individuals make decisions and receive information. Education also affects the intellectual in every person. Higher education will affect the broader view of the individual about everything, the amount of knowledge possessed, and easy to accept new ideas or ways in life. Otherwise, low education can affect the limitations of intellectual that make his behavior is still affected by the environment (Purwanto, 2004). A person who has higher education has better capability in receiving information than a person who have low education (Adi, 2004).

Occupation was the variables that are further investigated in this study. The analysis result showed that there was no significant correlation between the working patients and those who did not work on self-care agency with $p$ value of $1,000(>0,05)$. These findings are similar to Hassani, Farahani, Zohour, and Panahi (2010) that self-care and occupation do not show statistically significant relationships. Similar results were also obtained by Akyol, Cetinkaya, Bakan, Yarali, and Akkus, (2007) who also found that the occupation did not affect the ability of selfcare. Several other studies have also shown no significant relationship between occupation and the self-care agency of patients (Istek \& Karakurt, 2016; Aksel, 2010; Gul, Ustundag, \& Zengin, 2010). Different results obtained by Oksel, Akbiyk, and Koca (2009), there is a significant relationship between the work with the ability of a person in doing self-care. Work is directly related to one's self-care ability. Patients with better jobs are believed will earn a higher salary and impacted to his ability to use health services.

Patients who are still actively working and have good financial will help him in using health services adequately and also affect his participation in social life. Most of the respondents $(55 \%)$ in this study did not work and were generally housewives and retirees. However, this group of respondents still has income and health insurance from their families so that although they do not work they are still able to utilize the health service facilities optimally. This is why occupational status does not contribute to the patient selfcare agency.

The next variable that investigated in this study is marital status. The analysis result shows that there is no relationship of married and unmarried respondents with self-care agency with $\mathrm{p}$ value of 1.000 ( $>$ $0.05)$. Unmarried respondents $(50 \%)$ and married $(56.1 \%)$ both had more poor selfcare agencies than good self-care agencies. Unsar, Erol, and Mollaoglu (2007) also found no significant relationship between marital status and self-care agency of respondents. Other supporting studies were conducted by Khoshtarash, Momeni, Ghanbari, Salehzadeh, and Rahmatpour (2013) on factors related to self-care behavior in patients with systolic heart failure. The results also showed no effect between marital status on self-care behavior in patients with systolic heart failure.

The different result obtained by Daryasari, 
Dendi Kharisna : The Factors that are Related to Self-Care Agency in Patients with Hypertension

Karkezloo, Mohammadnejad, Vosooghi, and Kagi (2012) in their study of patients with heart failure. The result shows that married respondents have better self-care ability than unmarried respondents. Married respondents will have a spouse who can play a role in reducing job stress, providing emotional support and lifestyle changes that lead to improved patient self-care. Similar results were obtained by Istek and Karakurt (2016) in their research on self-care agencies in type 2 diabetic patients. They found there was a significant relationship between marital status and self-care agency. Unmarried respondents had higher self-care agency scores than married or divorced and single parent respondents. Mohamadi et al (2015) also stated that there is a significant relationship between marital status toward self-care behavior with $\mathrm{p} 0.008$. Respondents who have a spouse have a positive impact of creating affective support and helping patients to change lifestyles and improve self-care behavior in a better direction.

Married respondents have good support in the form of affection, material, information and evaluation from their partner. The patient will have basic and primary sources of strong social support from intimacy with their partner. Relying on and trusting their partner will help the patient in making decisions whereby the partner plays a role in monitoring patients self-care behavior and reminds the patient to always concern about their self-care behavior (Alizadeh, Ashktorab, Nikravan, Mofrad, \& Zayeri, 2014). Dunbar, Clark, Quinn, Gary, and Kaslow (2008) added that marital status is a necessary part of social support for patients with cardiovascular disease. Mortality and morbidity rates are found to increase in individuals who live alone and unmarried. Patients with unmarried heart failure are reported to be more depressed and have a lower quality of life and many are treated repeatedly to the hospital. Married and having a life partner provides a mechanism and an impact that is believed to provide social support so as to improve patient selfcare. With the support of social and family, patients can avoid psychosocial distress that can be bad for health behavior.

The difference this study with other studies may be caused by respondents socio-cultural factors. Respondents who are married or unmarried commonly ask for opinions to other family members, such as parents, brother, sister, and or other close relatives in deciding about their health problems. Discussion has become commonplace done by respondents before taking a decision or action to be done about their health problems. Respondents tend to listen to suggestions and suggestions from family members, especially those with similar experiences related to selfcare actions to be performed. Unmarried respondents continue to receive attention, affection, and support and support from their parents and immediate family, whether in decision-making related to health issues or about healthy daily living behaviors. This is why the marital status is not related to the self-care agency.

The subsequent analysis on decisionmaking variables indicate that decisionmaking either self-resolved by the respondent or through discussion is not related to selfcare agency with $p$ value of $0.800(>0.05)$. Decision-making is closely related to family support and the presence or absence of a patient's life partner. Dunbar, Clark, Quinn, Gary, and Kaslow (2008) say that family support has a positive effect on take care and maintaining healthy behavior. However, if the patient is too dependent on the family and the decision is entirely in the family then it also does not have a positive impact on the patient. In decision-making about intervention or response to patient's health condition must be done with good communication between patient and family. Patients should not take unilateral decisions, but also discuss with family members. Patients who consider their family as supporters, reinforcers, confidants and preferred alternatives have better health behaviors.

The family involvement to make decision for evaluation and interpretation the symptoms can can help patient response. Lack of cooperation or family care where the patient self-determines and takes full responsibility for himself without being accompanied by the family can make the patient anxious and distressed. As a result the patient will not be able to maintain healthy behavior and perform self-care optimally (Dunbar, Clark, Quinn, Gary, \& Kaslow). 
Dendi Kharisna : The Factors that are Related to Self-Care Agency in Patients with Hypertension

Baylis, Steiner, Fernald, Crane, and Main (2003) said that increased levels of depression are very related to decreased patient self-care abilities.

Other variables studied were duration of hypertension. Based on analysis result known that there is no significant correlation between duration of hypertension with selfcare agency, $\mathrm{p}$ value $0.567(>0.05)$. These results are similar to Saleema, Panpakdee, Arpanantikul, and Chai-Aroon (2016) studies suggesting that duration of hypertension does not affect the patient self-care agency as well as self-care behavior toward controlling hypertension. The same results were also obtained by Kusniawari (2011) in his research on factors that contribute to selfcare of diabetic patients. The study showed there was no significant association between long-standing Diabetes Mellitus (DM) with self-care diabetes.

Several studies also shown similar results that duration of DM did not affect the selfcare of diabetes. Patients who have recently suffered from DM and newly diagnosed actually have better self-care than patients who have long exposed to DM. the leading cause is patients who are newly diagnosed with DM have not been saturated in self-care activities and have high motivasion and responsibilities in controlling disease (Skinner \& Hampson, 2001; Sousa, Zauszniewski, Musil, Lea, \& Davis, 2005).

The results of this study are supported by the inconsistency of several studies about the relationship between duration of hypertension with self-care in controlling hypertension. Research conducted by $\mathrm{Hu}$, $\mathrm{Li}$, and Arao (2013) on factors related to self-care behavior in hypertensive patients in Beijing. Their findings suggest there is a positive relationship between duration of hypertension and self-care. Patients with long-standing hypertension tend to have better self-care than newly diagnosed hypertensive patients. Patients who have a longer duration of hypertension have learned how to adapt with hypertension so they will have a better self-care rather than the new patients with hypertension. This study also support by Vivience et al (2007) and Bai, Chiou, and Chang (2009) which suggest that self-care of diabetic patients is influenced by the length of patients suffering from DM. The longer the patient has DM the self-care ability of the patient will be better than the patient who suffer from DM with a shorter duration.

Bai, Chiou, and Chang (2009) explain that patients with long-lasting DM (more than 10 years) usually study diabetes self-care behavior based on the their experience. The patient becomes more prepared and better understanding of what should be done and what should not be done in maintaining their health status. Usually patients who suffer DM longer also understand the importance of self-care diabetes that tends to be active in finding various sources of information about diabetes care.

Therefore, there are several things that can occur in hypertensive patients. For new patients with hypertension still have high motivation and responsibility so that the patient is trying to implement self-care optimally. For patients who have recently suffered hypertension, it becomes a special experience and challenge to be able to do self-care well and prevent complications. For patients who have long suffered from hypertension, the patient is able to adapt and have a good understanding of the disease and committed to applying self-care as a habit and part of his life. Beside that, most of the respondents were unable to control their blood pressure have low both of comorbid and complications, so the respondent thought that they was healthy and done enough selfcare to maintain their health. This is why duration of hypertension is not related to selfcare agency.

The next variable studied is lifestyle. The results showed that lifestyle was related to self-care agency of respondents with $p$ value $0.003(<0.05)$. There is a positive relationship between lifestyle and self-care agency. The better the lifestyle the better the self-care agency of the respondent. Recommended lifestyles for patients with hypertension include eating a healthy diet, maintaining weight, performing regular physical activity, stress management, limiting salt intake and smoking or drinking alcohol (Huang, Duggan, \& Harman, 2008).

The study result from Istek and Karakurt (2016) on the influence of daily activities 
Dendi Kharisna : The Factors that are Related to Self-Care Agency in Patients with Hypertension

on self-care agency in patients with type 2 diabetes shows that there is a positive correlation between physical activity in daily life with self-care agency. The more physical activity increases the behavior and self-care agency of the patient. Other similar studies from Daryasari, Karkezloo, Mohammadnejad, Vosooghi, and Kagi (2012) suggest that poor self-care behaviors are associated with low physical activity in patients with heart failure. This is supported by Mohamadi et al. (2015) on self-care behavior in patients with systolic heart failure. The results showed poor exercise and weight control resulted in poor patient self-care behavior.

Another supportive study was carried out by Sundsli, Soderhamn, Espnes, and Soderhamn (2012) who in their study found that respondents who actively engaged in physical activity each day had better self-care ability than respondents who were physically active only once a week $\mathrm{p}<0.001$ ). There is a difference in the ability of self-care in respondents who perform physical activity every day compared with those who only do activities less than once a week or not physically active $(\mathrm{p}<0.001)$.

Istek and Karakurt (2016) in their research also mentions that there is a relationship between maintaining a good diabetes diet against self-care agency. Adherent patients and maintaining a healthy diet have higher self-care agency scores than patients who are not adherent to their diet. Unsar, Erol, and Mollaoglu (2007) also stated that in general dialysis patients maintaining a healthy and balanced dietary intake had a better self-care agency than patients who did not maintain a healthy and balanced diet.

Self-care management in patients with hypertenson is in line with lifestyle modification suggestions that focus on controlling risk factors which can increase blood pressure and worsen the patient's hypertension condition. Therefore, if patient able to modify their lifestyle into better lifestyle so it will also reflect the good selfcare of the patient as well. As outlined in the self-care model for patients with hypertension developed by Sadeghi et al. (2013), patients with hypertensive should be able to modify their lifestyle assisted by health personnel in the nearer area of health care service.
This concerned to improve and modify the lifestyle of patients with hypertension to achieve health and quality of life optimally. Therefore, the relationship between lifestyle with self-care agency is in the daily healthy lifestyle behavior that will have affect on the respondents ability in controlling blood pressure. Good lifestyle is part of good self-care and directly influence risk factors control of hypertension and contributes to the patient's ability to perform self-care.

The analysis result on the next variable shows the relationthip between health insurance with self-care agency of respondent ( $p$ value $0.027<0.05$ ). This study findings explained that the majority of respondents who have health insurance have a good self-care agency $(54.4 \%)$, whereas respondents who do not have health insurance have not good self-care agency (69.8\%). Akyol, Cetinkaya, Bakan, Yarali, \& Akkus (2007) also obtained the same result that there is a relationship between the ownership of insurance against self-care agency. Respondents who have health insurance are better able to take advantage of existing health facilities and use them to control and improve their health status and health care.

The same result is also expressed by Becker, Gates, and Newson (2004) in their research which aims to see the effect of access to health care on self-care applications in African Americans who have chronic illness. The results show that individuals who have health insurance are more able to develop and approach a self-care program. Ownership of health insurance guarantees the individual to gain access to sustainable health services and has the potential to optimize his self-care strategy and management of chronic illness. The ownership of health insurance is related to the ability of patients in access and utilizing the sources of health services. Patients who have health insurance are commonly also supported by sufficient socioeconomics that make them have surplus income and saving it for personal health needs. Patients who have lack of ability in using health facilities caused by cost limitedness and it becomes one of the inhibiting factors in the implementation of self-management in chronic diseases (Schneider, 2010).

The development of self-care strategy is 
Dendi Kharisna : The Factors that are Related to Self-Care Agency in Patients with Hypertension

influenced by the patient's ability to access health services. Access to health services can differentiate the way of patients cope with chronic illness. Patients who have health insurance have better opportunity to discuss with health personnel about their illness condition and obtain important information and also reinforcement of activities which aimed to prevent and handle the disease. The interactions between patients and health workers would potentially produce a comprehensive and effective self-care approach especially in chronic diseases (Becker, Gates, \& Newson, 2004).

Becker, Gates, and Newson (2004) added that patients who do not have health insurance have limited access to existing health services. Beside that, it is also significantly affects the patient's ability to develop selfcare completely and influence acceptance of self-care both culturally and biomedically. This leading case is supported by Callaghan (2005) who said that the ownership of health insurance increases patients self-care ability. Based on these findings, it clearly showed that the relationship between health insurance and self-care agency is in improving access to health services, increasing the opportunity to get information related to the disease and its management, and also increasing utilization of health facilities so that respondents can implement self-care independently and optimally. The leading case conclude that the health insurance has contribution to self-care agency.

Based on the results of multivariate analysis found that from nine factors studied, lifestyle became the most factor associated with self-care agency. Mersal and Mersal (2015) in their study about the effect of implementation lifestyle based on evidence on self-care behavior and self efficacy in patients with hypertension in Egypt. The results show there is a very positive correlation between the application of lifestyles that based on evidence to self-care activities. Patients who aplly lifestyle accordance with the guidelines as recommended are able to perform selfcare well such as limiting salt intake, losing weight to ideal weight, doing regular physical exercise, stopping smoking, not consuming alcohol, stress management, increased consumption of fruits and vegetables, reduced saturated fat consumption, and adherence to treatment.

These lifestyle modification help the patient in lowering and controlling their blood pressure thus reducing the complications of hypertension. As a first line on the management of hypertension, lifestyle modification has been shown to be effective in lowering blood pressure and suppressing the incidence of hypertension. Mersal and Mersal (2015) also stated that lifestyle guidance from NICE (The National Institute for Health and Care Exellence) enhanced the patient's self-care activity compared to patients who did not do lifestyle modifications as recommended.

The close relationship between lifestyle and self-care is also explained by Shrivastava, Shrivastava, and Ramasamy (2013) in patients with diabetes mellitus. Diabetic patients are also encouraged to conduct self-care activities as well as hypertensive patients based on recommendations. Self-care activities in daily living such as regulating diet, doing proper physical activity, adhering to medication therapy and monitoring blood sugar associated with a positive lifestyle and good self-care behavior as well. Alteration in self-care activity can also evaluated on changes in the patient's daily behavior.

A good lifestyle is essential in prevention of high blood pressure and can not be separated from the management of patients with hypertension. In JNC (Joint National Committee) 8 said that the role of lifestyle modification is always emphasized in the hypertensive management. Lifestyle modification by increasing physical activity and increasing control of obesity, dyslipidemia and diabetes mellitus are proved can provide benefits for cardiovascular health (Gavriilaki, Nikolaidou \& Gkaliagkousi, 2013). If the patient able to implement good lifestyle, so he will be able to treat himself.

Healthy lifestyles such as maintaining ideal body weight, eating low-salt foods and cholesterol, doing physical activity regularly or exercise, able to manage stress well, control blood pressure regularly, and adherence to treatment are part of hypertension management which should be able to be done patients especially in patients with grade I hypertension (blood pressure 140-159 mmHg / 90-99 mmHg) (James et al., 2013). 
Dendi Kharisna : The Factors that are Related to Self-Care Agency in Patients with Hypertension

This leadin case is accordance with this syudt findings where the majority of respondents have grade I hypertension. Multivariate analysis results showed that respondents have a good self-care agency 1.059 times $(95 \% \mathrm{CI}$ : 1.029-1.090) in respondents who have good lifestyle. Therefore, respondents are required to be able to apply lifestyle modifications as recommended to avoid complications of hypertension so that the goal to control blood pressure can be achieved.

\section{Conclusion}

Based on the research findings factors that are related to the self-care agency of patients with hypertension in Pekanbaru, so the conclusion from this study are the characteristics of patients with hypertension in Pekanbaru in Puskesmas Harapan Raya work area mostly in the age range 41-60 years, women, elementary school, unemployment, marriage, discussions in make decisions about health condition, duration of hypertension 1 to 3 years, have health insurance, and have a bad lifestyle. Most of the respondents in this study had a poor self-care agency. Factors related to self-care agency of hypertensive patients in Pekanbaru are age, gender, education, health insurance, and lifestyle. Meanwhile unrelated factors such as ocupation, marital status, decision making, and duration of hypertension. Lifestyle is the most associated factor with self-care agency in patients with hypertension after controlled with age variables.

\section{References}

Adi, R. (2004). Metodologi penelitian sosial dan hukum. Jakarta: Granit.

Akhter, N. (2010). Self-management among patient with hypertension in Bangladesh [Thesis]. Prince of Songkla University.

Akyol, A. D., Cetinkaya, Y., Bakan, G., Yarali, S., \& Akkus, S. (2007). Self-care agency and factors related to this agency among patients with hypertension. Journal of Clinical Nursing, 16, 679-687.
Allen, J. E. (2011). Nursing home administration. (6th ed.). New York: Springer Publishing Company.

Alizadeh, Z., Ashktorab, T., Nikravan, Mofrad, M., \& Zayeri, F. (2014). Correlation between perceived social support and selfcare behaviors among patients with heart failure. JHPM, 3 (1), 27-34.

American Heart Association [AHA]. (2007). High blood pressure increase risk of reduced function in older ages. Diperoleh tanggal 29 Maret 2014 dari http://www.americanheart. org/presenter.

Baghaiy, P. (2005). Self-care condition in diabetic patients in Kashandiabetic cancer. Feyz J, 12 (1), 88-93.

Bai, Y. L., Chiou, C. P, \& Chang, Y. Y. (2009). Self-care behavior and related factor in older people with type 2 diabetes. Journal of Clinical Nursing, 18, 3308-3315.

Bayliss, E. A., Steiner, J. F., Fernald D. H., Crane, L. A., \& Main, D. S. (2003). Descriptions of barriers to self-care by persons with comorbid chronic diseases. Ann Fam Med, 1 (1).

Becker, G., Gates, R., \& Newson, E. (2004). Self-care among chronically ill AfricanAmericans: Culture, health disparities, and health insurance. American Journal of Public Health, 94 (12), 2066.

Burn, N., \& Grove, S. K. (2005). The practise of nursing research: Conduct, critique, and utilization. (5th ed.). Missouri: Elsevier Saunders.

Burrow, L., \& Muller, R. (2007). Chronic kidney disease and cardiovascular disease: Pathophysioligic links. Nephrology Nursing Journal, 34, 55-65.

Callaghan, D. M. (2005). Healthy bhaviours, self efficacy, self-care, and basic conditioning factors in older adults. Journal of Community Health Nursing, 22, 169-178.

Coyle, R. L. (2000). Information retrieval of 
Dendi Kharisna : The Factors that are Related to Self-Care Agency in Patients with Hypertension

self-care and dependent care agents using net wellness [dissertation]. Ohio: The College of Nursing of Cincinnati University.

Dahlan, M. S. (2010). Besar sampel dan cara pengambilan sampel dalam penelitian kedokteran dan kesehatan. (edisi 3). Jakarta: Salemba Medika.

Daryasari, G, A., Karkezloo, N. V., Mohammadnejad, E., Vosooghi, M. N., \& Kagi, M. A. (2012). Study of self-care agency in patients with heart failure. Iranian Journal $d$ Critical Care Nursing, 4 (4), 203-208.

Dinas Kesehatan Kota Pekanbaru. (2015). Profil kesehatan kota pekanbaru tahun 2015. Pekanbaru: Dinas Kesehatan Kota.

Dinas Kesehatan Propinsi Riau. (2012). Profil kesehatan propinsi riau 2012. Pekanbaru: Dinas Kesehatan Propinsi Riau.

Dinas Kesehatan Propinsi Riau. (2013). Profil kesehatan propinsi riau 2013 Pekanbaru: Dinas Kesehatan Propinsi Riau.

Dunbar, S. B., Clark, P. C., Quinn, C., Gary, R. A., \& Kaslow, N. J. (2008). Family influences on heart failure self-care and outcomes. $J$ Cardiovasc Nurs, 23(3), 258-265. DOI: 10.1097/01.JCN.0000305093.20012.b8.

Gavriilaki,E.,Nikolaidou,B., \& Gkaliagkousi, E. (2013). Exercise in patients with essential hypertensiion: Current consepts. Gen Med (Los Angel), 1 (2).

Gul, A., Ustundag, H., \& Zengin, N. (2010). The evaluation of self-care agency in renal transplant patients. General Medical Journal, 20, 7-11.

Hajjar, I., \& Kotchen, T. A. (2003). Trends in prevalence, awareness, treatment, and control of hypertension in the united states, 1988-2000. Journal of American Medical Association, 290, 199-206.

Hassani, M., Farahani, B., Zohour, A. R., \& Panahi, A. (2010). Self-care ability based on Orem's theory in coronaryaartery disease patients. Iranian Journal of Critical care
Nursing, Summer 2010, 3 (2), 87-91.

Hu, H., Li, G., \& Arao, T. (2013). Prevalence rates of self-care behaviours and related factors in a rural hypertension population: A questionnaire survey. International Journal of Hypertension, 2013, 1-8.

Huang, N., Duggan, K., \& Harman, J. (2008). Lifestyle management of hypertension. Australian Prescriber, 31 (6), 150-153.

Istek, N., \& Karakurt, P. (2016). Effect of activity daily living on self-care agenccy in individuals with type 2 diabetes. Journal of Diabetes Mellitus, 6, 247-262.

James, P. A., Oparill, S., Carter, B. L., Cushman, W. C., Dennison-Himmelfarb, C., Handler, J., . . . Ortiz, E. (2013). 2014 evidence-based guideline for management of high blood pressure in adults: Report from the panel members appointed to the eight joint national commite (JNC 8). JAMA, E1E14. Doi:10.1001/jama.2013.284427.

Kamrani, A. A., Foroughan, M., Taraghi, Z., Yazdani, J., Kaldi, A., Ghanei, N., \& Mokhtarpoor, R. (2014). Self care behaviour among elderly with chronic heart failure and related factors. Pakistan Journal of Biological Sciences, 17, 1161-1169.

Kementerian Kesehatan RI. (2013). Riset kesehatan dasar. Diperoleh tanggal 28 Maret 2014 dari http://www.depkes.go.id/ downloads/riskesdas2 $013 /$ Hasil\%20 Riskesdas\%202013.pdff.

Khresheh, R., \& Mohammed, N. (2016). Self-care behaviors among women with hypertension in Saudi Arabia. IOSR Journal of Nursing and Health Science, 5(3), 52-56. DOI: 10.9790/1959-0503035256.

Khroshtarash, M., Momeni, M., Ghanbari, A., Salezhzadeh, A. H., \& Rahmatpour. P. (2013). Self-care behaviors and related factors in patients with heart failure reffering tp medical \& educational center of heart in Rasht. Holistic Nursing and Midwifery Journal, 23(1), 22-29.

Krishnan, A., Garg, R., \& Kahandaliyanage, 
Dendi Kharisna : The Factors that are Related to Self-Care Agency in Patients with Hypertension

A. (2013). Hypertension in the South-East Asia region: An review. Regional Health Forum, 17 (1), 7-14.

Kusniawati. (2011). Analisis faktor yang berkontribusi terhadap self-care diabetes pada klien diabetes melitus tipe 2 di rumah sakit umum Tangerang [Tesis]. Depok: Fakultas Ilmu Keperawatan Universitas Indonesia.

Meleis, A. I. (2012). Theoritical nursing: Development and progress. (5th ed.). Philadelphia: Lippincott Williams \& Wilkins.

Mersal, F. A., \& Mersal, N. A. (2015). Effect of evidence based lifestyle guidelines on self efficacy of patient with hypertension. International Joural of Current Microbiology and Applied Sciences, 4(3), 244-263.

Messerli, F. H., Williams, B, \& Ritz, E. (2007). Essential hypertension. Lancet, 370, 591-603.

Mohamadi, S. Z., Alhani, F., Shakoor, M., Farmani, P., Fahidi, F., Mohseni, B., \& Taherpazir, E. F. (2015). Self-care bahaviors in patients with systolic heart failure. Journal of Nursing and Midwifery Sciences, 2(1), 46-54.

Ogah, O. S., Okpechi, I., Chukwuonye, I. I., Akinyemi, J. O., Onwubere, B. J. C., Falase, A. O., .. Sliwa, K. (2012). Blood pressure, prevalence of hypertension and hypertension related complications in Nigeria Africans: A review. World J Cardiol, 4 (12), 327-340.

Oksel, E., Akbiyk, G., \& Koca, K. G. (2009). Self-care behavior analysis of patients with chronic heart failure. Eur J Cardiovasc Nurs, 31(8), 22-26.

Onwuchekwa, A. C., Asekomeh, E. G., Iyagba, A. M., \& Onung, S. I. (2010). Medical mortality in the accident and emergency unit of the university of port harcourt teaching hospital. Niger J Med, 17, 182-185.

Orem, D. E. (2001). Nursing: Concepts of practice. (6th ed.). St. Louis: Mosby.
Potter, P. A., \& Perry, A. G. (2009). Basic nursing: Essentials for practice. Mosby: Elsevier.

Purwanto, M. N. (2004). Psikologi Pendidikan. Bandung: Remaja Rosdakarya.

Ranpenning, K., \& Taylor, S. G. (2003). Self-care theory in nursing: selected paper of dorothea orem. New York: Springer Publishing Company.

Riskesdas. (2013). Riset kesehatan dasar. Jakarta: Badan Penelitian dan Pengembangan Kesehatan Kementerian Kesehatan RI.

Riskesdas. (2007). Hipertensi di Indonesia. Diperoleh tanggal 25 Maret 2014 dari http:// www.depkes.go.id.

Roger, V. L., Go, A. S., Llyod-Jones, D. M., Benjamin, E. J., Berry, J. D., Borden, W. B., ... Turner, M. B. (2012). Heart disease and stroke statistics. American Heart Association, e2e9. DOI: 10.1161/CIR.0b013e31823ac046.

Sadeghi, M., Shiri, M., Roohafza, H., Rakhshani, F., Sepanlou, S., \& Sarrafzadegan, N. (2013). Developing an appropriate model of self-care hypertensive patients: firts experience from EMRO. ARYA Atherpscler, 9(4), 232-240.

Saleema, L., Panpakdee, O., Arpanantikul, M., \& Chai-Aroon, T. (2016). The influence of basic conditioning factors and self-care agency on self-care behaviors in Thais with hypertension. Pasific Rim Int J Nurs Res, 20 (1), 5-17.

Sastroasmoro, S. (2011). Dasar-dasar metodologi penelitian klinis. (edisi 4.). Jakarta: Sagung Seto.

Schneider, C. (2010). Chronic disease: Accesss to health care and barriers to selfmanagement. Winnipeg Regional Health Authority.

Shrivastava, S. R., Shrivastava, P. S., \& Ramasamy, J. (2013). Role of self-care in management of diabetes mellitus. Journal 
Dendi Kharisna : The Factors that are Related to Self-Care Agency in Patients with Hypertension

of Diabetes \& Metabolic Disorders, 12(14), $1-5$.

Skinner, T. C., \& Hampson, S. E. (2001). Personal models of diabetes in realtion to self care, wellbeing and glycemic control: A prospective study in adolescence. Diabetes care, 24(5), 828-833.

Smeltzer, S.C., Bare, B.G., Hinkle, J.L., \& Cheever, K. H. (2010). Brunner and Suddarth's textbook of medical-surgical nursing. (12th ed.). Philadelphia: Lippincott Williams \& Wilkins.

Soderhamn, U., \& Bachrach-Lindstrom, M. (2008). Self-care ability and sense of coherence in older nutritional ar-risk patient. Eur J Clin Nutr, 62 (1), 96-1-3.

Sousa, V. D., Zauszniewski, J. A., Musil, C. M., Lea, P. J. P., \& Davis, S. A. (2005). Relationship among self-care agency, self efficacy, self-care, and glycemic control. Reasearch and Theory for Nursing Practice: An International Journal, 9(3), 61-67.

Srikan, P. (2012). The relationship of basic conditioning factors, knowledge, self-care agency, self-care behaviour, and urinary sodium excretion of hypertensive older adults: Testing orem's self-care theory. Knoxville: University of Tennessee.
Sundsli, K., Soderhamn, U., Espnes, G, A., \& Soderhamn, O. (2012). Ability for self-care in urban living older people in southern Norway. Journal of Multidiciplinary Healthcare, 5, 85-95.

Unsar, S., Erol, O., \& Mollaoglu, M. (2007). The self-care agency in dialyzed patients. Dyalisis \& Transplantation, 1-7.

Vivienne, S. F., Courtney, M., Edwards, H., McDowell, J., Shortridge-Bagget, L. M., \& Chang, P. (2007). Self-efficacy, outcome expectation and self care behaviour in people with type 2 diabetes in Taiwan. Journal Compilation, 250-256.

Weinger, K., Beverly, E. A., \& Smaldone, A. (2014). Diabetes self-care and theolder adult. West J Nurs Res, 36 (9), 1272-1298.

World Health Organization [WHO]. (2013). World Health Day 2013: Measure your blood pressure, reduce your risk. Diperoleh tanggal 22 April 2017 dari http://www.who.int.

Yang, G., Kong, L., Zhao, W., Wan, W., Zhai, Y., Chen, L. C., \& Koplan, J. P. (2008). Emergence of chronic non-communicable diseases in China. The Lancet, 372 (9650), 1697-1705. 